\title{
RESENHA
}

\section{REPENSANDO O MUNDO PARA TEMPOS PÓS-CORONAVÍRUS: As lições esperançosas de Edgar Morin}

\author{
Taline Sabany Velasques \\ Rafael Montoito2
}

MORIN, E. É hora de mudarmos de via: as liçōes do coronavírus / Colaboração: Sabah Abouessalam; Tradução: Ivone C. Benedetti. 1. ed. Rio de Janeiro: Bertrand Brasil, 2020.

A obra de Edgar Morin tem como contexto a pandemia causada pelo novo coronavírus, trazendo reflexões a respeito das consequências já observadas, e ainda vivenciadas, em nível mundial. O autor é referência em diversas pesquisas atuais do campo da Educação e sua obra tem contribuído e potencializado discussões sobre diversos assuntos - em destaque, a Teoria da Complexidade, da qual é o maior representante. Como obra literária, o livro é dividido em preâmbulo, introdução, capítulo 1 (As 15 lições do coronavírus), capítulo 2 (Os desafios pós-corona), capítulo 3 (A mudança de via) e conclusão. Embora trate de um assunto atual e bastante delicado, a escrita de Morin clama à esperança que cada leitor pode ter, em si, deixado adormecer.

No preâmbulo da obra, Morin salienta a pseudo ideia do homem que acreditava já ter domínio da natureza, fazendo um breve resgate histórico de datas e acontecimentos que ajudaram a construir, ao longo da história da humanidade, essa ideia: antes do ano de 1980 e do aumento nos casos da AIDS, acreditava-se que o homem havia eliminado todos os vírus e

\footnotetext{
1 Mestre em Design, Universidade do Vale do Rio dos Sinos (Unisinos); Instituto Federal de Educação, Ciência e Tecnologia Sul-riograndense (IFSul); Pelotas, RS, Brasil. Orcid iD: https://orcid.org/0000-0002-6668-9571. E-mail: talinesv@gmail.com

2 Doutor em Educação para a Ciênia (UNESP); Instituto Federal de Educação, Ciência e Tecnologia Sul-riograndense (IFSUl); Pelotas, RS, Brasil. OrcidiD: https://orcid.org/0000-00023294-3711. E-mail:xmontoito@gmail.com
} 
bactérias existentes; antes de 2008, asseverava-se a exclusão de toda e qualquer crise; já antes de 2020, acreditava-se que a humanidade havia banido as grandes epidemias. Em 2020, no entanto, a ideia de que o homem ocidental dominara a natureza cai por terra diante da visualização de uma nova pandemia viral, cuja primeira evidência foi em 2019, na China. O resultado foi uma crise sanitária sem precedentes, que até hoje ainda está sendo vivenciada. Seus impactos e consequências a nível mundial são inestimáveis: o mundo parou e, embora distintas áreas tenham sido afetadas com isso, os impactos sobre a economia e a educação parecem ser mais facilmente perceptíveis - e suficientes para que se entenda urgente e necessário repensar a forma de viver e as políticas públicas para conter o seu avanço. Morin ressalta que, apesar de existir registro de pandemias anteriores na história, a de Covid-19 ocasionou o que chamou de "megacrise", desmascarando a fragilidade e precariedade esquecida e ocultada em função de uma ideia de segurança e domínio das máquinas, tecnologias e, principalmente, ciência e natureza. Quando a sociedade tomou conhecimento do vírus, pouco se sabia a seu respeito - pesquisas e estudos ainda estão em andamento, pois novas variantes continuam surgindo -, de modo que fomos conhecendo com o que estávamos lidando à medida que vivemos com esta nova realidade. As incertezas são diversas: origem do vírus, propagação desigual, mutações, tratamentos, prevenção, políticas de contenção, políticas sociais, entre outros. Para algumas destas questões já existem respostas, porém o nosso modo de vida já está, de certa forma, modificado: a ação imediata do isolamento foi o modo de prevenção mais eficaz, diante de um cenário tão caótico e incerto; e, mesmo ainda isolados - total ou parcialmente, a depender da realidade de cada um -, o livro de Morin convida-nos a repensar os nossos hábitos como sociedade imersa nesta nova realidade e para o que advém. O preâmbulo ainda faz uma contextualização a respeito das principais crises e pandemias registradas na história, descrevendo um século de sucessivas mudanças e momentos históricos que ajudaram a forjar a sociedade dos dias atuais. Morin destaca que essa crise desencadeada pelo coronavírus pode ser 
entendida como tendo raízes bem mais antigas, pois é uma consequência dos velhos hábitos e da forma de viver alicerçada na falsa premissa de que o homem é o dominador da natureza e dos saberes.

O número de pessoas vivendo em isolamento social, em função desta pandemia, assusta: mais de quatro bilhões de pessoas, aproximadamente metade da população mundial. Os números até o momento da publicação do livro já eram preocupantem: 350 mil mortos; um ano depois, ultrapassa 3.489.17 mortos (mais de meio milhão apenas no Brasil). Se os números, por si só, já não fossem assustadores, o que vemos diariamente a respeito de como a vida se transformou bastaria para comprovar o inevitável: a forma de viver que conhecemos deu lugar ao momento mais confinado que já vivenciamos. Morin salienta que uma mudança de paradigma - que é o que estamos enfrentando - "é um processo longo, difícil, caótico, que esbarra em enormes resistências das estruturas estabelecidas e das mentalidades." (MORIN, 2020, p. 23). Apesar disso, o autor não tem uma visão pessimista a respeito do que estamos vivendo e discorre a respeito das consequências do isolamento social, seus problemas e da luta pela saúde pública, demonstrando uma visão de esperança a médio e longo prazo.

No capítulo 1, Morin aborda as 15 lições da pandemia para sociedade global, destacando os desafios que enfrentaremos como sociedade no mundo pós-pandemia. Dentre elas, as lições sobre nossa existência, em que traz questionamentos a respeito da forma como a sociedade vive, as suas reais necessidades, aspirações e desejos, por vezes reprimidos em prol de uma rotina mecanizada de casa-trabalho/trabalho-casa. Logo em seguida, apresenta as lições sobre a condição humana e chama a atenção para a necessidade de tomarmos consciência para a dualidade do paradigma do aumento do conhecimento proporcional ao aumento da fragilidade humana diante da natureza. Dentre outras, traz ainda lições sobre a natureza de uma crise e salienta a crise da inteligência, ou seja, uma lacuna nas reflexões a respeito dos temas apresentadas previamente, o que torna invisível a complexidade da nossa realidade. Por consequência, revela uma fraqueza na forma de conhecimento que é apresentado/ensinado, pois 
separa e compartimentaliza os saberes, ao invés de conectá-los. Além disso, se restringe a prever aquilo que é provável, ignorando o inesperado que surge constantemente. Outro ponto que o autor salienta é o fato de que o "antigo normal" não parece fazer mais sentido e, por isso, voltar a esta realidade, mesmo após a imunização suficiente da população, não é uma opção - ou, ao menos, não deveria ser. Além disso, faz uma contundente crítica aos hábitos e ritmo de vida desenfreados que possuíamos e aponta, como possíveis soluções, formas mais generosas para este novo normal: um mundo pós-pandêmico mais responsável, solidário, sustentável e com cooperação global. A análise é pertinente e facilmente compreensível porque é possível perceber, em função do isolamento social, uma consequência imediata: a renovação da natureza pouco tempo depois da diminuição do movimento nas cidades, nos transportes e nas indústrias, e, principalmente, a adesão a comportamentos humanos mais voltados à solidariedade e em defesa de políticas públicas para os mais necessitados.

Já no segundo capítulo, o autor apresenta uma problematização bastante crítica e provocativa a respeito dos impactos oportunizados por irregularidades e disparidades que possivelmente enfrentaremos no póspandemia, num rol amplo que abarca desde a prestação de serviços públicos até o enfraquecimento das democracias.

A crise pôs em xeque o neoliberalismo, substrato doutrinário das políticas praticadas no mundo desde os anos Thatcher-Reagan, que promovem a livre concorrência econômica como solução para todos os problemas sociais e humanos e preconizam a liberdade máxima para as empresas e um papel mínimo para o estado. Foi o neoliberalismo que inspirou a privatização dos serviços públicos, a redução e a comercialização dos serviços hospitalares, a prática dos fluxos e da deslocalização. (MORIN, 2020, p. 51-52).

Morin salienta que estas incertezas ficam evidenciadas a partir do momento em que os estados precisaram abandonar a austeridade orçamentária em prol de gastos com a saúde e com trabalhadores que ficaram desempregados. Políticas públicas de assistência social foram primordiais na tentativa de combate à desigualdade e aos problemas mais iminentes causados pela pandemia. No nível mais individual, salienta que o isolamento social é uma reclusão, mas também uma libertação dos velhos 
hábitos: tempo cronometrado, ritmo desenfreado e sobrecarga de trabalho são hábitos que podem vir a ser ressignificados, influenciando diretamente na qualidade de vida das pessoas. Por outro lado, há também uma segunda possibilidade: a de que, passada a pandemia, a sociedade recaia sobre a mesma rotina desequilibrada. Morin é parcial sobre estas duas direções: ele acena com esperança à superação da megacrise, mas entende que as mentes precisam despertar para isso - ir em busca de uma outra via.

Por fim, no capítulo 3, "Mudar de via", o autor apresenta uma ressignificação humanística e da sociedade, propondo mudanças que promovam uma maior qualidade de vida, com equilíbrio entre os novos hábitos da sociedade e o meio em que vivem. Neste sentido, apresenta uma explicação a respeito do termo escolhido: "Por que via, e não revolução? [...] "Por que via e não projeto de sociedade?" (MORIN, 2020, p. 62). A esse respeito, explica que revoluções produzem opressões que não condizem com os seus objetivos de emancipação; da mesma forma, não poderia ser um projeto de sociedade porque, neste caso, o termo diz respeito a uma noção estática que não é adequada a um mundo em transformação. As reflexões apresentadas anteriormente não apenas salientam retrocessos prováveis como é a partir delas que se aposta em um "despertar das consciências e das energias" (MORIN, 2020, p. 63), que pode vir a ser uma nova via. Uma nova via que englobe políticas nacionais, civilizacionais, da humanidade, da terra e, principalmente, que englobe um humanismo regenerado. Por isso, Morin defende uma reforma em todos os âmbitos da sociedade: social, política, econômica, empresarial, democrática, ecológica. A verdade é que a pandemia provocou uma parada forçada e colocou em dúvida muitas questões da atualidade. Os indícios mostram que a pandemia ainda terá efeitos por alguns anos e que a recuperação será lenta e aos poucos. Considerando que o mundo não será mais o mesmo, Morin alerta: o mundo pós-coronavírus é tão preocupante quanto a própria pandemia e já existem sinais suficientes sobre a possibilidade de ser um desastre - daí a necessidade de uma esperança prática e combativa. 0 futuro é de incertezas e ele está sendo formado neste momento. Por isso, o 
autor crava: "está na hora de mudar de via" (MORIN, 2020, p. 24). A mudança de via que propõe Morin diz respeito a rever as políticas públicas, as quais favorecerão a defesa dos novos dias a partir do que chama de humanismo regenerado, ou seja, que "rejeita o humanismo de quase divinização do homem, voltado para a conquista e a dominação da natureza" (MORIN, 2020, p. 100), mas que entende e aceita a complexidade e as contraditoriedades do ser humano, que propõe uma vivência mais próxima da natureza, reconhecendo nossa ligação com a mesma e faz um uso consciente dos seus recursos, em conjunto com o conhecimento intelectual e cultural.

É imprescindível reconhecer o poder da natureza frente à humanidade e entender que a sua imprevisibilidade está acima de nós. Somente a ciência é capaz de apresentar soluções aos problemas enfrentados e, por consequência, o caminho mais provável para a sociedade em equilíbrio é a educação. Além disso, o olhar para com o outro e o entorno deve ser mais empático. Nas palavras de Morin, é necessária uma mudança pessoal e uma renovação da ética, compreendendo que não existe reforma da sociedade sem uma reforma pessoal em paralelo. $O$ livro inspira a pensar sobre o que tivemos que aprender a fazer de forma diferente de como fazíamos e sobre hábitos e ações que tivemos que pausar. A realidade que nos foi imposta, se não nos servir para uma reflexão, nos deixará apenas o caos que trouxe em forma de avalanche. A mensagem global do livro é a de que não basta sobreviver ao coronavírus: é necessário repensar e projetar um novo mundo, uma nova organização social e novos hábitos.

Recebido em: 28 de setembro de 2021 . Aprovado em: 23 de novembro de 2021.

Publicado em: 04 de dezembro de 2021. 